\title{
The recent landscape history of Limpach valley, Switzerland: considering three empirical hypotheses on driving forces of landscape change
}

\author{
Matthias Bürgi • Angela Straub • Urs Gimmi • \\ Daniel Salzmann
}

Received: 17 March 2009/Accepted: 21 September 2009/Published online: 1 October 2009

(C) Springer Science+Business Media B.V. 2009

\begin{abstract}
Understanding global landscape dynamics is a core challenge for the newly emerged field of land change science. Such an understanding requires insights into general pattern of landscape changes and the related driving forces. Many case studies of landscape change exist, but only few attempts have been made, to synthesize the results and to search for general pattern. We suggest that applying hypotheses on driving forces of landscape change derived from one case study in another region as a promising way to advance towards a more integrative view on landscape dynamics. Based on the conclusions drawn in a case study conducted in Godmanchester (Quebec, Canada; Domon and Bouchard 2007), we formulated three hypotheses and discussed them in a case study on landscape change in the Limpach valley, Switzerland. We confirm the importance of geomorphological characteristics for landscape development (hypothesis 1) and our analysis also supports the second hypothesis, which states that changes in demand for certain resources result in landscape change. However, we suggest replacing the term resources by the more encompassing concept of goods and services. The third hypothesis, which states that technological transformations stand at the beginning of landscape
\end{abstract}

M. Bürgi ( ( ) A. Straub · U. Gimmi · D. Salzmann WSL Swiss Federal Institute for Forest, Snow and Landscape Research, Research Group Land Use History, Zürcherstrasse 111, 8903 Birmensdorf, Switzerland e-mail: matthias.buergi@wsl.ch change, also was confirmed. Technologies have to be affordable, socially accepted, and corresponding to a demand, to be implemented on a large scale. This will cause a technological transformation, which thendepending on the specifics of the technology appliedbecomes relevant for landscape development. We conclude with three reworded hypotheses on driving forces of landscape change and we hope that they will be tested and further developed in other case studies.

Keywords Landscape history - Land use change · Ecosystem goods and services - Environmental history $\cdot$ Historical ecology $\cdot$ Switzerland ·

Peat land

\section{Introduction}

Landscapes are dynamic and landscape changes have been studied for a long time, with various cognitive interests and various scientific methods. Whereas many of the early studies on landscape change were conducted by historical geographers (for an excellent overview on the connections between geography and history see Baker 2003), later on, environmental historians, but also ecologists, landscape ecologists and global change researchers joined in. The ecologists' interest in landscape change is mostly motivated by the consequences of landscape changes for habitats, flora and fauna (Foster and Motzkin 2003; Schrott et al. 2005), but also by topics such as 
hydrology and watershed management (Pijanowski et al. 2007). Global change researcher focus on the impact of landscape change on regional climate (Schneider and Eugster 2007; Ramankutty et al. 2006), or on carbon pools (Tan et al. 2005). These approaches aim at assessing the consequences of landscape changes, often with a declared will to contribute to an improved future management for specific ecosystems, habitat types or species (Duncan et al. 1999; Pijanowski et al. 2007).

Other studies focus on the causes of the changes and try to understand the underlying driving forces (Bürgi and Turner 2002; Verburg et al. 2004). These studies aim at assessing long term trend of landscape evolution (e.g., Silbernagel et al. 1997), and at understanding how present land-use pattern developed (Andersen et al. 1996), or they try to determine rates of landscape change and the accelerating and decelerating factors therein (Schneeberger et al. 2007). One of the main motivations for studying the major trends, processes and driving forces of landscape change is to find general pattern that are valid beyond the specific situation under study, and to contribute herewith to the development of a general theory of landscape change. This aim is in line with Kates et al. (1990), who concluded from the papers collected in the volume "The earth as transformed by human action" (Turner et al. 1990) that a general theory of human-environment relationships would have to conceptualize (1) the relations among the driving forces of human-induced change, (2) the processes and activities among them, and (3) human behaviour and organization (see also Lambin and Geist 2006).

The time seems right to aim at a comprehensive and systematic integration of history in landscape ecology, i.e., to develop a theory of landscape change (Lambin and Geist 2006). Christensen's (1989) paper entitled "Landscape History and Ecological Change" and Wasson's (1994) paper "Living with the past: uses of history for understanding landscape change and degradation" are important starting points for this endeavour. Recent publications (e.g., Rhemtulla and Mladenoff (2007) "Why history matters in landscape ecology") and the newly emerged "science of land change" (e.g., Rindfuss et al. 2004; Lambin and Geist 2006) underline how timely attempts are, to foster the integration of history into landscape ecology.

There are several ways, how to move towards a theory of landscape change, such as statistical procedures, configurational comparisons and metaanalyses (Young et al. 2006). Alternatively, we propose to apply hypotheses derived from one case study in a different region. Linking two case studies in such a manner, enables to determine more general pattern and processes in landscape changes, and avoids simply adding one case study after the other. Often, it will not be possible to conduct a rigorous test of the hypotheses, as not all relevant aspects can be quantified or transformed in a way to be included in statistical analyses. We opt to consider descriptive approaches, incorporate circumstantial evidence, narratives, and inferential reasoning for such integrative analyses of landscape change (Bürgi and Russell 2001; Bürgi et al. 2004).

We decided to work with the study by Domon and Bouchard (2007), who formulated three conclusions on core properties of landscape change based on impressive and comprehensive research, conducted over 25 years, in the landscape of Godmanchester (Quebec, Canada). They state that "First, changes rarely occur in a uniform way on territories: they remain closely associated to the geomorphological characteristics of the territories. [...] Second, no matter how determining they are, the biophysical characteristics never operate on their own: landscape transformations are always the expression of a socioeconomic demand for a specific resource. [...] ...the historical reconstruction of Godmanchester illustrates rather well the determining role of a third factor that acts as a kind of mediator of the first two. The technological transformations stand out indeed as being at the origin of the shifts between anthropic and biophysical relationships and, thus, at the origin of landscape transformations."

Based on these three conclusions, we formulated three hypotheses on driving forces of landscape change:

(a) Landscapes changes remain closely associated to the geomorphological characteristics of the territories.

(b) Landscape changes are the expression of socioeconomic demand for a specific resource.

(c) Technological transformations stand at the origin of landscape changes.

We considered these empirical hypotheses in a case study on landscape change in the Limpach valley, Switzerland, where excellent historical 
sources were found, which is a core prerequisite for conducting landscape history analyses. Historical analyses are only possible if appropriate and ample sources are available. The Limpach valley remained primarily rural in character over the last few centuries - the same holds true for Godmanchester. We assume that this similarity facilitates the adoption of the conclusion on landscape change drawn in the study in Godmanchester as hypotheses for the study of the Limpach valley. In our study we wanted to know how and why the formerly vast wetlands of the Limpach valley were transformed throughout the last centuries (Straub 2008). We therefore focus our analysis on changes in the open land, i.e., leaving aside the changes in settlement and forest area.
Study area

The Limpach valley, is located in the central Lowlands of Switzerland, on the Swiss Plateau (Fig. 1). The study area encompasses eight municipalities (Limpach, Mülchi, Unterramsern, Oberramsern, Messen, Balm bei Messen, Ruppoldsried, Wengi) and covers an area of about $30 \mathrm{~km}^{2}$. It stretches over two cantons, i.e., the Canton of Solothurn, and the Canton of Berne (Fig. 1). The main valley floor, which is surrounded by wooded hills, is about $13 \mathrm{~km}$ long with an average width of $1-2 \mathrm{~km}$ and is located at 465-500 masl. Today, the Limpach valley is still a rural region, but employment has to be found largely outside of the Valley. Many of the 2,884 inhabitants
Fig. 1 The Limpach valley is located in the lowlands of Switzerland. The study area (black line) encompasses eight municipalities (not shown) and is split between the Canton of Solothurn and the Canton of Berne. The grey shaded box stands for the perimeter of Fig. 2, depicting the Wengimoos (Data: BFS GEOSTAT/ swisstopo)

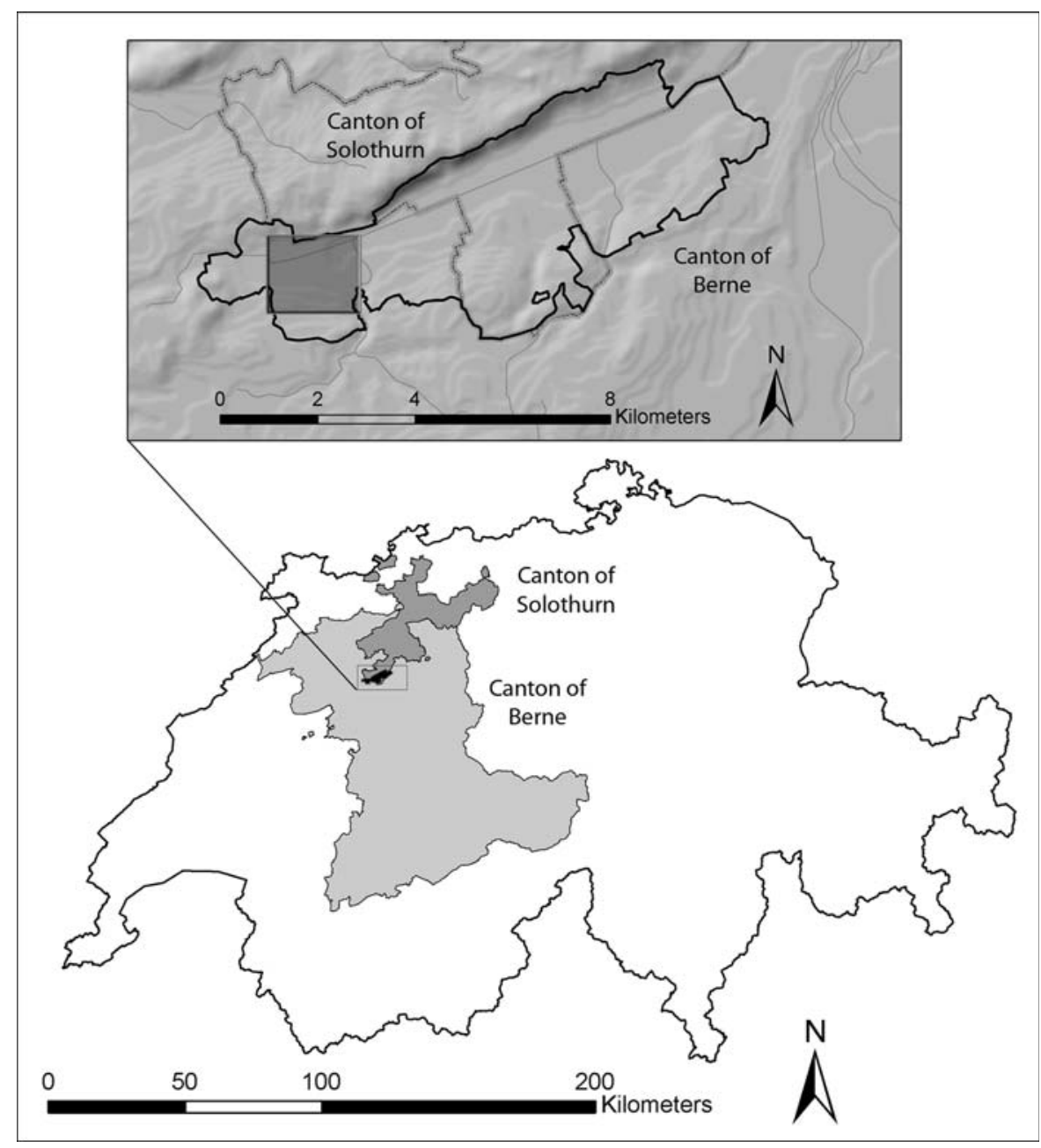


(http://www.fin.be.ch/; http://www.so.ch/) commute to nearby larger towns and cities, such as Berne, the capital of Switzerland, which is only about $20 \mathrm{~km}$ away (Luterbacher 1992).

The soils in the study area are organic, partly peaty soils on the valley floor and mineral soils on the surrounding slopes and hills. In the 1940s, the average depth of the peat layer varied from 100 to $300 \mathrm{~cm}$ (Stähli 1941). Today, due to peat mining and drainage with subsequent mineralization, this depth is generally reduced, with high spatial variability. The yearly average precipitation is $1,000-1,100 \mathrm{~mm}$ and the average temperature $8.5^{\circ} \mathrm{C}$ (Luterbacher 1992).

\section{Materials and methods}

The main sources for reconstructing the landscape and land use history of the Limpach valley were written and cartographic documents, terrestrial photographs, and secondary literature (e.g., Stähli 1941, 1953) most of which were found at local, state, and federal libraries and archives. From the eighteenth to the twentieth century, maps depicting the course of the river Limpach and its tributary were available. Especially valuable maps derive from the planning, realization, and reporting of a land melioration project conducted between 1939 and 1951. These maps at the scale of 1:5,000 depict topics such as land use, drainage, ownership structure, and parceling (published in Stähli 1953). For the development in the second half of the twentieth century, six oral history interviews with local farmers or people with a close connection to agricultural development in the study area were conducted. Additional expert interviews supplemented information on the most recent period.

Combining information from various sources, including quantitative as well as qualitative data, is characteristic of historical ecology (Bürgi and Gimmi 2007) and integrative studies of landscape change (Bürgi and Russell 2001). A source critical approach, commonly used in historical sciences, has to be applied and careful testing and evaluating, if possible by comparison of different source types or statistical methods, is crucial. In the study presented, a largely descriptive approach was followed. Based on secondary literature, it was known that landscape history in the Limpach since the eighteenth century was mainly driven by various melioration projects, transforming wetlands to agricultural soil. A timeline of references on melioration projects, but also other landscape related activities was compiled based on written documents, secondary literature, and for the most recent time, oral history interviews. The various maps allowed putting this information in a spatial context for the respective point in time. Repeat photography provided information on small-scale changes and on changes in landscape appearance. More detailed information on the source types and methods applied is given in Straub (2008).

\section{Results}

Landscape change in the Limpach valley before 1900

Between 1400 and 1800, the Swiss lowlands were mostly part of the agrarian zone called "Grainland" (Mathieu 1992), in which the arable land was cultivated according to the three field system: a third of the land was sown in turn with winter grain (spelt, rye), the second third with summer grain (oats, barley), and the third part remained fallow. The cattle grazed on the common pasture, on the fallow fields, and on the grain fields after the harvest (Pfister 1983). The demand for agricultural land led to clearing of forests in the pre-alps, and early drainage projects in the lowlands, where the valley floors often consisted of waterlogged organic soils and peat land. This was also the case in the Limpach valley, where a large proportion of the low laying valley floor was common lands, mostly used as poor pasture (Müller 1804 in Stähli 1941), whereas cropland, which was managed in the three field system, was restricted to the higher grounds (Müller 1804 in Stähli 1941). First attempts to drain the valley floor in the Limpach valley date back to the fifteenth century. In the 1740 s, some municipalities started to straighten out the course of the Limpach and its tributaries (Stähli 1941), however, without much success. Other municipalities followed in the second half of the eighteenth century (Neuhaus 2006), motivated by a report that draining the land would convert the wet meadows in valuable hay land and even allow the production of grain in the plain. By the beginning of the nineteenth century, the three field system has been largely abandoned in 
the study area. This development stands at the core of changes triggered by the agrarian revolution, which affected land use in large parts of Europe (Pfister 1983; Lowod 1987). Periodically, the Limpach still flooded large parts of the Limpach valley, fostering discussions on further canalizing and draining. However, deciding on a common project was difficult as two cantons and several municipalities were involved. In 1860, a new drainage project targeting the marshland Scheunenberg-Wengi was implemented (Wyss 1929). It included the construction of four simple channels without fortification (visible on Fig. 2 north of the village of Wengi). In this period, industrially produced drainage tubes made of clay became available and fostered drainage projects all over Central Europe. In the Canton of Berne, within a few years, close to $5,000,000$ drainage tubes were produced at comparatively low costs and 1,600 ha of wetlands were drained (Pfister 1995). The ovens, in which these tubes were produced, required stone coal and consequently the existence of railroads which were rapidly spreading in the second half of the nineteenth century.

Whereas some land was drained, large parts remained wetland, i.e., "Moos". In some parts of the "Moos", peat was dug, dried, and stored in small huts (see Fig. 2). In the canton of Berne, the use of peat as heating material started at around 1730 (Hirt 2007). No exact date can be given, when peat mining started in the study area, but it is likely that smallscale operations were taken up in the nineteenth century.
Fig. 2 The placename "Moos" in the topographical map of 1880 refers to mires. The huts distributed throughout the "Moos" were probably used to store peat. [Data: Siegfriedmap first edition 1880, No. 139 (GrossAffoltern) modified. 2009, swisstopo (DV 033492.2), reproduced with permission of swisstopo (J082265)]

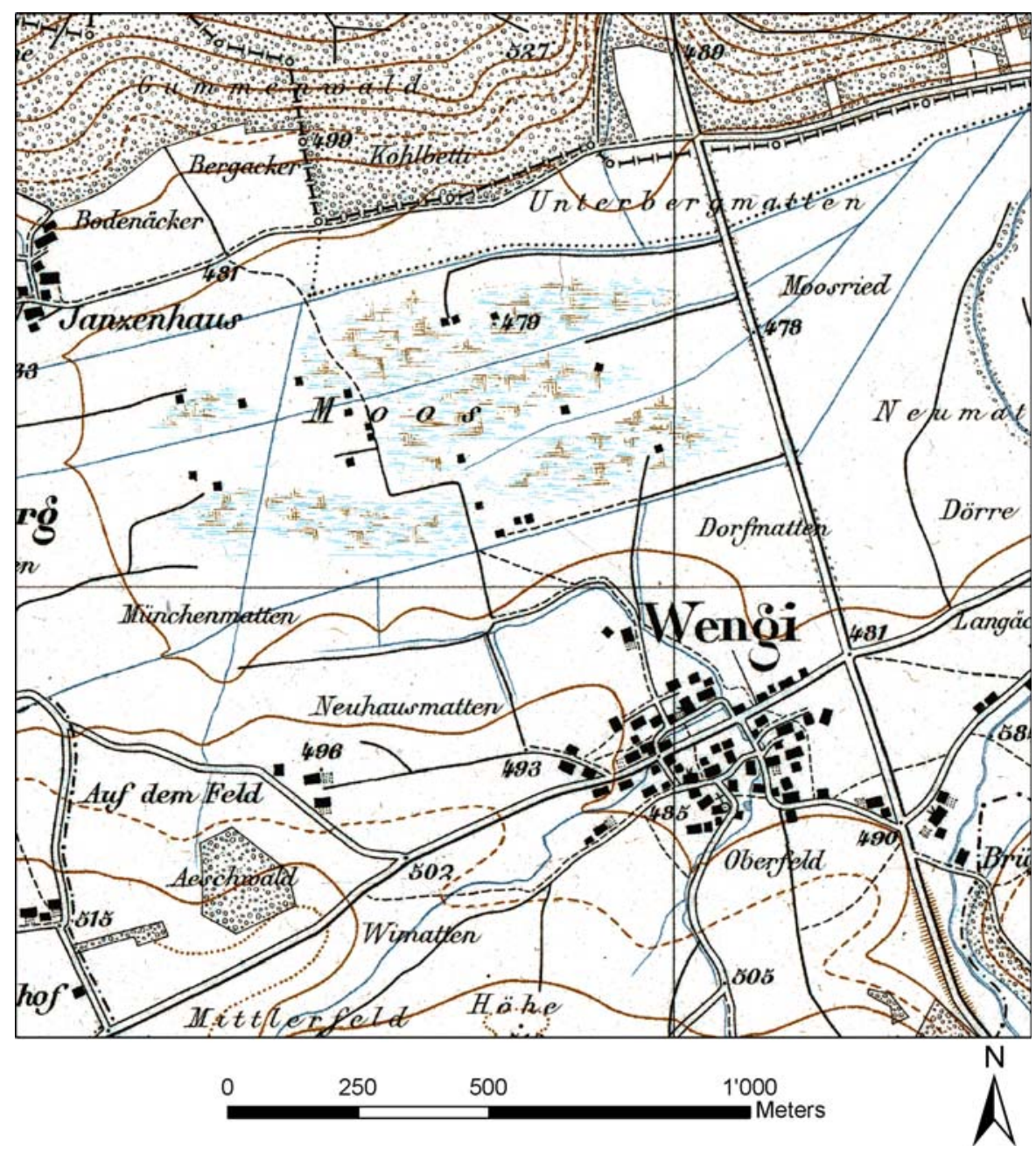


Landscape change in the Limpach valley:

the first half of the twentieth century

At the beginning of the twentieth century, agriculture in the Limpach valley was still dominated by small family-holdings, mostly engaged in subsistence farming (C. Wyss, personnel communication). The parcels of one farm were distributed widely throughout the municipalities and-due to inheritance pattern and the limited accessibility by lanes-often of irregular shape, e.g., $700 \mathrm{~m}$ long and $10 \mathrm{~m}$ wide. Most lowlying parts of the valley were natural meadows, which were cut 2-3 times a year. Contemporary descriptions reveal that the villages, surrounded by orchards and gardens, were like islands in the vast valley floor, which was used as pasture, meadow or cropland, depending on the soil-water-content. Various channels crossed the valley floor and provided some drainage towards the rivulet Limpach. In many parts, the groundwater table was very close to the surface, as the riverbed of the Limpach itself was quite high. In 1929, about 200 ha of land, in the western part of the valley was still swampland (Letter 1929). Cropland was restricted to the higher parts of the valley and covered about $36 \%$ of the agricultural area (Bangerter 1939). Dairy farming and the production of butter and cheese for outside markets was of some importance, but fruits, vegetables and eggs were foremost produced for local demand.

Periodically, the valley was flooded-events which punished bold farmers, who expanded cropland to lower parts of the valley. Farmers perceived a steady worsening of the situation. A major flood in 1939 (Fig. 3) significantly raised the willingness to take counter measures (Stähli 1941). Additionally, the beginning of World War Two marked the start of a vast federal program, to enhance agriculture and to increase self sufficiency of Switzerland. Therefore, it was the right time to re-activate long-grown plans for a comprehensive melioration project, encompassing 2,325 ha of the Limpach valley (Stähli 1953). The project, conducted between 1939 and 1951, consisted of lowering and further straightening out of the bed of the Limpach river, corrections of its tributaries, and drainage of 1,664 ha of land. For the latter, $877 \mathrm{~km}$ of drainage pipes were laid. The parcels were reallocated, to allow for more efficient farming, i.e., the number of parcels was reduced from 5,743 to 1,070 . Consequently, the average number of parcels by farm

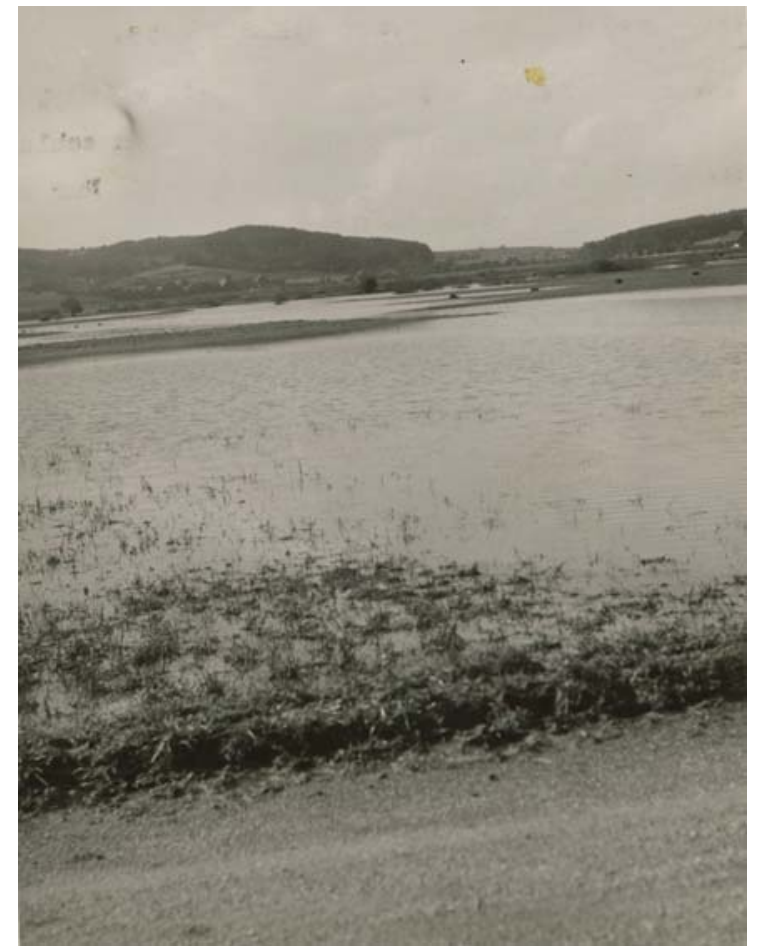

Fig. 3 Flooding of the Limpach in Oberramsern, 14.10.1939 (Source: photo reproduced in Bangerter 1940)

decreased from 8.5 to 2.2 and their average size increased from 0.04 ha to 0.217 ha. Additionally, $114 \mathrm{~km}$ of new tracks were built, and $10.6 \mathrm{~km}$ of old tracks were improved (Stähli 1953).

World War Two did not only increase the demand for domestic agricultural products, but also for domestic energy resources. Consequently, peat was in high demand. The largest accumulations of peat in the Limpach valley were located in the wettest parts of the valley, the Wengimoos, with peat layers of up to $5 \mathrm{~m}$. Especially after 1942 , peat production in the Wengimoos was professionalized and went from private persons to companies (Bangerter 1944). At the peak of the peat-rush, up to 1,000 workers were engaged in peat mining in the Wengimoos (Fig. 4), including detained polish soldiers who were kept in a so-called "concentration camp" in the nearby city of Büren an der Aare (Roder 2007).

By 1943, the melioration process, working his way up from the lower end of the valley to the municipalities higher up along the Limpach, had reached the municipality of Wengi. At this point, a vivid conflict between the federal office, which was in charge of increasing agricultural production 


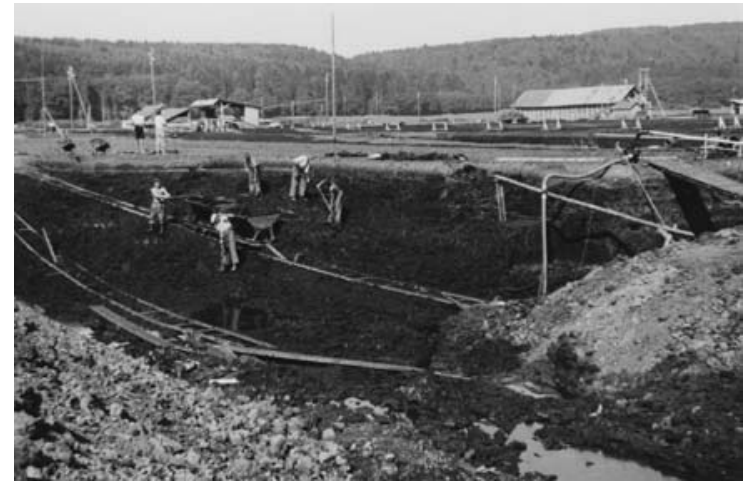

Fig. 4 Peat mining in the Wenigmoos, Sept/Oct 1942. The watertable was lowered by pumps (visible on the right side) (Source: Archive "Abteilung für Sturkturverbesserungen und Produktion des Amtes für Landwirtschaft und Natur des Kantons Bern")

("Kriegswirtschaftsamt") and the federal office of energy supply ("Amt für Kraft und Wärme") broke out. The federal office of energy supply asked for a perimeter for peat production and threatened with a cut in subsidies for the heavily subsidized melioration project. Finally, a core part of the Wengimoos was set aside for peat production and left out from further drainage ("Torfabbaugebiet" in Fig. 5). Until March 1944 , about $40,000 \mathrm{~m}^{3}$ of peat were extracted from the Wenigmoos (Protokoll 1944). Peat production seized after World War Two.

Landscape change in the Limpach valley: the second half of the twentieth century

After its completion in 1951, the melioration project was assessed a major success: "Where on swampland and acid meadows only meagre plants were growing, today, we find beautiful fields and productive artificial meadows. The project changed the whole landscape, beautifying the whole region and the canton." (own translation of: "Wo einst auf sumpfigen sauren Wiesen nur eine spärliche Flora gedieh, befinden sich heute schöne Äcker und ertragreiche Kunstwiesen, sodass das gesamte Werk des Landschaftsbild wohl von Grund auf geändert, aber in der neuen Form der ganzen Gegend und dem Kanton zur Zierde gereicht"). However, it was admitted, that "...a poetic aspect of our homeland has vanished for ever" (own translation of: “....ein Stück Poesie unserer Heimat unwiederbringlich verlorengegangen ist”) (Stähli 1953).

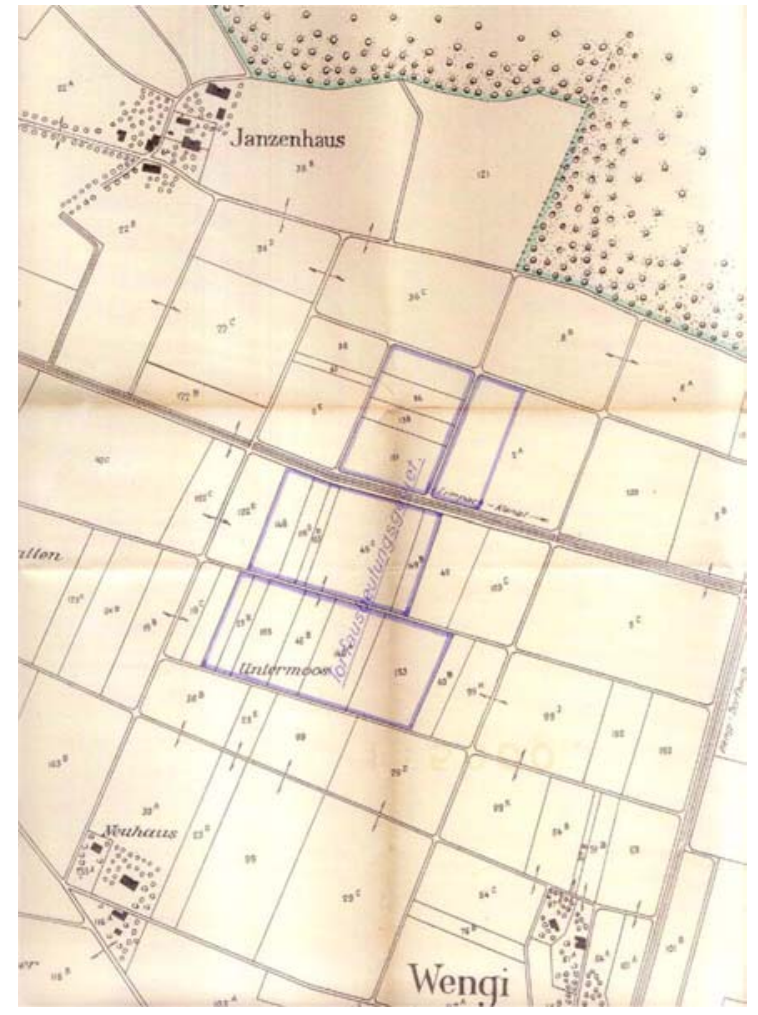

Fig. 5 Map from 1944, depicting the peat mining area ("Torfausbeutungsgebiet") in which drainage was banned. Today, this area hosts a nature reserve, i.e., the Wengimoos (map reproduced in Bangerter 1944)

The part of the Wengimoos, which was set aside for peat production and consequently was not converted in agricultural land, was perceived as a „kulturtechnisches Muttermal”, i.e., an eyesore for the engineers. In the course of the second half of the twentieth century, this eyesore experienced a complete and radical reinterpretation also by the public at large. The peat digging era resulted in a highly structured landscape in the Wengimoos, interspersed with ponds of various sizes. Nature conservationists soon realized the ecological value of these diverse habitats in the otherwise monotonous agricultural landscape of the Limpachtal. In 1959, a first plot of about 3 ha got in the hands of the local bird protection club (ALA, Bernische Gesellschaft für Vogelkunde und Vogelschutz). Two years later, a protection perimeter of 33 ha was established, which still belonged to 25 different owners. In the 1970s, nature conservationists realized that simply setting aside areas which contained valuable habitats was not 
enough, as these ecological values were at threat by succession-a core characteristics of most habitats created by human activities. In the Wengimoos, active management for nature conservation started in 1977, when reed was mown, shrubs were removed, and shallow ponds newly dug-and even blasted (Büro Mosimann und Strebel 2001). These measures were successful and the periodic mowing and removing of shrubs continued. In 1994, 8.44 ha of the Wengimoos were included in the Federal Inventory of Fenlands (Büro Mosimann und Strebel 2001) and a few years later, the Wengimoos became part of the Federal Inventory of Amphibian Spawning Areas (Büro Mosimann und Strebel 2001). Additionally, the Wengimoos today is on the list of wetlands of the canton of Berne and listed as important place for migrant waders (Schmid et al. 2002). A vegetation analyses conducted in 1999, lists 190 plant species for the Wengimoos, two of which are listed as heavily threatened on the relevant Red List (Landolt 1991), i.e., Cicuta virosa and Calamagrostis canescens, and eight more are listed as threatened (Büro Mosimann und Strebel 2001). More than 150 bird species have been observed in the area (Friedli 2006), among which 40 are breeding regularly. The reserve requires an ongoing intensive management; otherwise succession would turn it into a "Bruchwald" (i.e., marshland forest-Straub 2008).

\section{Discussion}

Hypothesis 1: landscape change and geomorphology

Our first hypothesis derived from Domon and Bouchard (2007) states that landscapes changes remain closely associated to the geomorphological characteristics of the territories. Does this also hold true in the Limpach valley?

Today, it is common local knowledge that the Wengimoos is different from the rest of the Limpach valley because it is protected (Straub 2008). However, our study reveals that it is the other way round: The Wengimoos is protected because it already was on a completely different trajectory of change than the rest of the Limpach valley at the time, when first protection measures were taken. The split in trajectories was based on the fact that the Wengimoos is located in a part of the study area which has been named as the wettest part repeatedly. Thus, this area was not only a valuable resource for peat production, but also least suitable for agriculture. The split in trajectories of landscape change, which bears all the characteristics of a human-mediated vegetation switch sensu Wilson and King (1995), was based on geomorphological differences in the study area, in combination with conflicting demands for different resources, i.e., agricultural products and peat.

Based on our study in the Limpach valley, we therefore can confirm the importance of the geomorpholocical characteristics for landscape development, as stated in the first hypothesis.

Hypothesis 2: demand for resources as a major driving force of landscape change

Our second hypothesis states that landscape changes are the expression of socio-economic demand for a specific resource. The major process of landscape change in the Limpach valley between 1700 and 2000 is the conversion of an originally vast wetland into intensively managed farmland. But it was not until the massive melioration project in the 1940s that the drainage was completely successful, i.e., a significant intensification of farming became possible. A prerequisite for the implementation of the melioration project was the increased demand for domestic agricultural products during World War Two. This demand, however, stood in conflict with an increase in demand for domestic energy resources, resulting in a split in trajectories of landscape change, as outlined above.

Since the 1970s, the Wengimoos has actively been managed to become an outstanding habitat for wetland species. Our analysis of the landscape history of the Limpach valley and the Wengimoos illustrates, how strong and far reaching the human imprint on the Wengimoos was. Consequently, it is wrong to interpret today's conditions as natural, despite the conservation measures are motivated and performed as restoration measures. The conversion of an abandoned peat-mining landscape to a nature reserve of federal importance was triggered by the demand for habitats for rare species and for nature reserves in an otherwise rather monotonous agricultural landscape.

What does this mean in terms of the second hypothesis? We confirm that changes in demand for certain resources initiate many changes. However, 
demands do not only address resources, but a wide range of ecological, socio-cultural, and economic services. Therefore we propose to replace the term resources by the encompassing concept of ecosystem goods and services (de Groot et al. 2002), and to reformulate the hypothesis accordingly.

Hypothesis 3: the role of technology in landscape development

The third hypothesis states that technological transformations stand at the origin of landscape changes. Indeed, the landscape changes in the Limpach valley reflect the development of drainage techniques very well. Lowering and diverting of the riverbed required heavy machinery, and the large-scale drainage required the use of drainage tubes, which both were not available in the eighteenth century. However, the early drainage projects were not very effective. The development of industrially produced drainage tubes made of clay was a crucial innovation for the spread of drainage projects in Central Europe and stands at the beginning of widespread conversion of wetlands.

Agriculture experienced a rapid development in the course of the agrarian revolution. Between the late eighteenth century and about 1830 s, innovations, such as the seeding of clover in the fallow, the largescale planting of potatoes, the indoor feeding of cattle during summer, and the construction of underground reservoirs for collecting dung-water reformed Central Europe's agriculture profoundly (Pfister 1995). The motorization started in the $1880 \mathrm{~s}$, and additionally fueled the mechanization of agriculture. It is important to be aware that some technology used extensively in the late nineteenth century, was already available since the early nineteenth century, but as long as cheap labor was available, its use was of no interest to the average farmer (Pfister 1995). Mechanization and motorization enabled farmers to work larger areas efficiently without additional labor force, which became more and more expensive due to the demand for workers in the industry. Agriculture was further intensified by the increasing availability of affordable artificial fertilizer and agrochemicals which were also imported by railroads.

Our case study implies that a specific economic and infrastructural context determines if and how certain technology leaves traces in the landscape. Technologies allow the societal demand for goods and services to be fulfilled in a specific and historically characteristic way. They do not just have to be available, but they also have to affordable, socially accepted and corresponding to a demand.

Therefore, the third hypothesis, which states that technological transformations stand at the beginning of landscape change, also seems to be true. To underline the prerequisites of a technological transformation, we propose to highlight that technologies have to be affordable, socially accepted, and corresponding to a demand, to be implemented on a large scale, i.e., that a technological transformation takes place, and becomes relevant for landscape development.

How representative is the Limpach valley for landscape development in central Europe?

Our study has been conducted in a region which was dominated by agriculture throughout the study period and we restricted the study area to the parts dominated by agriculture. Landscape development in Central Europe however, is not simply shaped by intensification of agriculture and newly arisen concerns for endangered species and habitats. In a recent study on landscape change in a more urbanized and industrialized part of the Swiss lowlands, Hersperger and Bürgi (2009) distinguished between three main trends of landscape change, i.e., urbanization, intensification, and greening - the latter including measures taken to improve the ecological values in farmland and settlements. In Switzerland as a whole, the main trends of landscape change in the nineteenth and twentieth centuries are a steady expansion of forest areas in remote areas where farming no longer is profitable and a similarly steady expansion of settlements on agricultural land in the lowlands, based on a high demand for living space of a growing and affluent population (BFS 2001).

In this study, we focused our attention on the changes in the open land, neglecting the development of forests and settlements. We chose this study area and design to discuss three hypotheses based on the findings of Domon and Bouchard (2007), which also studied a primarily agricultural landscape. It is an open question to what extent our findings are also valid in landscapes that involve different land cover types with their specific sets of goods and services and the related driving forces. 


\section{Conclusions}

Our approach, to translate conclusions from one case study into hypotheses for another case study in a different region, was successful. We worked with hypotheses derived from a study conducted by Domon and Bouchard (2007) and we are now in the position to partly reformulate the hypotheses as follows:

(1) Landscape changes remain closely associated to the geomorphological characteristics of the territories.

(2) Landscape changes are the expression of a socio-economic demand for specific ecosystem goods and services.

(3) Technology determines how the demand for certain goods and services are translated into land use. New technologies have to be affordable, socially accepted, and corresponding to a demand to be applied widely and to cause a technological transformation and consequently a landscape transformation.

For the analytical framework of driving forces of landscape change, five different groups of driving forces are distinguished, i.e., natural, cultural, political, socioeconomic, and technological driving forces (Bürgi et al. 2004). Our results imply that natural driving forces, e.g., the geomorphological characteristics, form the template, on which political and socioeconomic driving forces determine what technology is applied and transforms the landscape. Convincing concepts, how the various dimensions of cultural driving forces can be integrated in studies of landscape changes are still missing, despite there is general agreement that culture leaves deep imprints in the land (e.g., Nassauer 1995, 1997; Naveh 2001).

We hope that the reformulated hypotheses from our study will be considered or even tested in other studies and again reformulated according to the new findings.

Acknowledgments We thank Anna M. Hersperger, Peter B. Pearman, and two anonymous reviewers for helpful comments on this manuscript.

\section{References}

Andersen O, Crow TR, Lietz SM, Stearns F (1996) Transformation of a landscape in the upper mid-west, USA: the history of the lower St. Croix river valley, 1830 to present. Landsc Urban Plan 35:247-267

Baker ARH (2003) Geography and history. Bridging the divide. Cambridge studies in historical geography 36

Bangerter H (1939) Melioration des Limpachtales-plan über Kulturarten 1:5,000. Fraubrunnen. Abt. f. Strukturverbesserungsmassnahmen des Amts f. Landwirtschaft des Kantons Solothurn

Bangerter H (1940) Technischer Bericht und Kostenvoranschlag der Melioration des Limpachtales. Fraubrunnen, 3.7.1940. Abteilung für Sturkturverbesserungen und Produktion des Amtes für Landwirtschaft und Natur des Kantons Bern

Bangerter H (1944) Bericht zur Ergänzung des Projektes Melioration Wengi. Betrifft speziell Torfausbeutungsgebiet vom 20. Oktober 1944. Abteilung für Sturkturverbesserungen und Produktion des Amtes für Landwirtschaft und Natur des Kantons Bern

BFS (2001) The changing face of land use. Land use statistics of Switzerland. Swiss Federal Statistical Office, Berne

Bürgi M, Gimmi U (2007) Three objectives of historical ecology: the case of litter collecting in central European forests. Landscape Ecol 22(Suppl 1):77-87

Bürgi M, Russell EWB (2001) Integrative methods to study landscape change. Land Use Policy 18:9-16

Bürgi M, Turner M (2002) Factors and processes shaping land cover and land cover changes along the Wisconsin river, USA. Ecosystems 5:184-201

Bürgi M, Hersperger A, Schneeberger N (2004) Driving forces of landscape change-current and new directions. Landscape Ecol 19:857-868

Büro Mosimann und Strebel (2001) Naturschutzgebiet Nr. 4.1.1.41 Wenigmoos. Pflege-und Gestaltungskonzept

Christensen NL (1989) Landscape history and ecological change. J For Hist 33:116-125

de Groot RS, Wilson MA, Boumans RMJ (2002) A typology for the classification, description and valuation of ecosystem functions, goods and services. Ecol Econ 41:393-408

Domon G, Bouchard A (2007) The landscape history of godmanchester (Quebec, Canada): two centuries of shifting relationships between anthropic and biophysical factors. Landscape Ecol 22:1201-1214

Duncan BW, Boyle S, Breininger DR, Schmalzer PA (1999) Coupling past management practice and historic landscape change on John F. Kennedy Space Center, Florida. Landscape Ecol 13:291-309

Foster DR, Motzkin G (2003) Interpreting and conserving the openland habitats of coastal new England: insights from landscape history. For Ecol Manage 185:127-150

Friedli D (2006) Das Naturschutzgebiet Wengimoos. In: Affolger M (ed) Wengi. Vereinigung für Heimatpflege Büren, pp 20-23

Hersperger AM, Bürgi M (2009) Going beyond landscape change description: quantifying the importance of driving forces of landscape change in a central Europe case study. Land Use Policy 26:640-648

Hirt H (2007) Torfstechen im seeland-Gewinnung des Rohstoffes Torf bei Energieversorgungslücken seit dem 18. Jahrhundert. In: Berner Zeitschrift für Geschichte und Heimatkunde 69(1):39-76

Kates RW, Turner BL, Clark WC (1990) The great transformation. In: Turner BL et al (eds) The earth as transformed 
by human action. Global and regional changes in biosphere over the past 300 years. Cambridge University Press, Cambridge, pp 1-81

Lambin EF, Geist HJ (2006) Land-use and land-cover change. Local processes and global impacts. Springer, Berlin

Landolt E (1991) Gefährdung der Farm und Blütenpflanzen in der Schweiz. BUWAL, Bern

Letter (1929) Schreiben der Gemeinde Wengi an die Landwirtschaftsdirektion Bern vom 29. August 1929, Amt für Strukturverbesserungen und Produktion des Amtes für Landwirtschaft und Natur des Kantons Bern

Lowod HE (1987) Patriotism, profit, and the promotion of science in the German enlightenment: the economic and scientific societies. PhD-Thesis, University of California, Berkeley, pp 1760-1815

Luterbacher J (1992) Das Limpachtal—geografische Übersicht und Stickstoffbelastung eines ländlichen Gebietes im Schweizer Mittelland. Zweitarbeit im Hauptfach Geographie am Geografischen Institut der Universität Bern, pp 1-59

Mathieu J (1992) Eine agrargeschichte der inneren alpen. Chronos, Zürich

Nassauer JI (1995) Culture and changing landscape structure. Landscape Ecol 10:229-237

Nassauer JI (1997) Placing nature. Culture and landscape ecology. Island Press, Washington, DC

Naveh Z (2001) Ten major premises for a holistic conception of multifunctional landscapes. Landsc Urban Plann 57:269-284

Neuhaus C (2006) Wie vor 200 Jahren das Wengimoos aufgeteilt wurde. In: Affolter $\mathrm{M}$ et al. (eds) Wengi. Drei Dörfer-eine Gemeinde. Hornerblätter 2006, Vereinigung für Heimatpflege Büren a/A.. S.4-7

Pfister C (1983) Changes in stability and carrying capacity of lowland and highland agro-systems in Switzerland in the historical past. Mt Res Dev 3:291-297

Pfister C (1995) Geschichte des Kantons Bern seit 1798. Band IV. Im Strom der Modernisierung. Bevölkerung, Wirtschaft und Umwelt 1700-1914. Bern 1995

Pijanowski B, Ray DK, Kendall AD, Duckles JM, Hyndman DW (2007) Using backcast land-use change and groundwater travel-time models to generate land-use legacy maps for watershed management. Ecol Soc 12(2):25 (online)

Protokoll (1944) Protokoll über die Konferenz mit sämtlichen Torfstechern im Wengimoos vom 7. März 1944. Gemeindearchiv Bätterkinden

Ramankutty N, Delire C, Snyder P (2006) Feedbacks between agriculture and climate: an illustration of the potential unintended consequences of human land use activities. Glob Planet Change 54:79-93

Rhemtulla JM, Mladenoff DJ (2007) Why history matters in landscape ecology. Landscape Ecol 22(Suppl. 1):1-3

Rindfuss RR, Walsh SJ, Turner BL, Fox J, Mishra V (2004) Developing a science of land change: challenges and methodological issues. Proc Natl Acad Sci 101:1397613981

Roder W (2007) Wengi bei Büren BE-die Perle im Limpachtal
Schmid H, Leuenberger M, Schifferli L, Birrer S (2002) Limikolenrastplätze der Schweiz. Schweizerische Vogelwarte Sempach, p 159

Schneeberger N, Bürgi M, Kienast F (2007) Rates of landscape change at the northern fringe of the Swiss Alps: historical and recent tendencies. Landsc Urban Plann 80:127-136

Schneider N, Eugster W (2007) Climatic impacts of historical wetland drainage in Switzerland. Clim Change 80:301321

Schrott GR, With KA, King ATW (2005) On the importance of landscape history for assessing extinction risk. Ecol Appl 15:493-506

Silbernagel J, Martin SR, Gale MR, Chen J (1997) Prehistoric, historic, and present settlement patterns related to ecological hierarchy in the eastern upper Peninsula of Michigan, USA. Landscape Ecol 12:223-240

Stähli H (1941) Das Limpachtal und seine Bodenverbesserung. Buchdruckerei Fritz Glauser, Fraubrunnen

Stähli H (1953) Die Melioration des Limpachtales: 1939-1951. Buchdruckerei Fritz Glauser, Fraubrunnen

Straub A (2008) Die Gesamtmelioration des Limpachtals von 1939 bis 1951 - und ihr Folgen für die Landnutzung und Landwirtschaft. Thesis conducted at WSL, Switzerland \& University of Karlsruhe, Germany

Tan ZX, Liu SG, Johnston CA, Loveland TR, Tieszen LL, Liu JX, Kurtz R (2005) Soil organic carbon dynamics as related to land use history in the northwestern Great Plains. Glob Biochem Cycles 19:GB3011

Turner BL, Clark WC, Kates RW, Richards JF, Mathews JT, Meyer WB (1990) The earth as transformed by human action. Global and regional changes in biosphere over the past 300 years. Cambridge University Press, Cambridge

Verburg PH, Ritsema van Eck JR, de Nijs TCM, Dijst MJ, Schot P (2004) Determinants of land-use change patterns in the Netherlands. Environ Plann B Plann Des 31:125150

Wasson RJ (1994) Living with the past: uses of history for understanding landscape change and degradation. Land Degrad Rehabil 5:79-87

Wilson JB, King WM (1995) Human-mediated vegetation switches as processes in landscape ecology. Landscape Ecol 10(4):191-196

Wyss C (1929) Technisches Bureau Chr. Wyss: untersuchung betr. die Entwässerungsmöglichkeiten des ScheunenbergWengi-Mooses d.h. des obersten Teiles des Limpachtales vom Januar 1929. Abteilung für Sturkturverbesserungen und Produktion des Amtes für Landwirtschaft und Natur des Kantons Bern

Young OR, Lambin EF, Alcock F, Haberl H, Karlsson SI, McConnell WJ, Myint T, Pahl-Wostl C, Polsky C, RamakrishnanP, Schroeder H, Scouvart M, Verburg PH (2006) A portfolio approach to analyzing complex humanenvironment interactions: institutions and land change. Ecol Soc 11:31 [online]. URL: http://www.ecologyand society.org/vol11/iss2/art31/ 